\title{
KONTROLLORROLLER I STORE OG SMÅ INSTITUSJONER
}

\author{
Av Per Ole Johansen
}

\section{PROBLEMET}

\section{Restriktive og liberale kontrollørroller}

Restriktiv eller liberal behandling av klientene, personlig kontakt eller avstand til dem man står i et autoritetsforhold til? Slike spørsmål har vært klassiske for så mang slags »kontrollører«.

I en undersøkelse i 1968 av ansatte på 6 husvilleherberger i en av våre største byer ${ }^{1)}$ fulgte jeg opp den problemstillingen. Klientellet på herbergene var bostedsløse menn, eller herbergister som det også het. De ansatte ble kalt »kontrollører«, og deri lå en antydning av hva arbeidet besto i. Flere karakteriserte seg som »herbergets politimenn« da de ble bedt om å beskrive yrket. Men det var flere måter å kontrollere klientellet på, som det også fantes myke og harde polititeknikker:

»Ute på gangen hvor vi alle er samlet så støtter vi den mannen som har tatt en avgjørelse, men ellers er det liksom to linjer som rår. Det er snakk om en silkefront versus den mere tradisjonelle stilen.«

»Der er to grupper her. Den ene gruppa har liberale innstillinger overfor løsgjengerproblemene, og har også et mere rolig og avslappet forhold til herbergistene. Den andre gruppa, som er i flertall, holder herbergistene mere på avstand og interesserer seg ikke noe særlig for disse.«

Den restriktive kontrollørrollen var autoritetsreden, og bygde på avstand av klienten. En slik rolleinnehaver så på fysisk makt som en uunngåelig, om enn ikke ønskelig metode i de mest tilspissede situasjoner. Her var relativt skeptisk til herbergistene, som han omtalte på en tildels fordømmende måte.

Den liberale kontrollørrollen bygde på overtalelse og diskusjon fremfor fysisk makt. Liberaleren var ikke så engstelig for å slippe herbergistene inn på livet av

1) Undersøkelsen ble brukt til magistergraden i sosiologi i 1970. Artikkelen bygger på materialet. På noen punkter har jeg benyttet meg av opplysninger som ble samlet inn i 1968, men som ikke ble brukt i magistergradsavhandlingen. I hovedsak har jeg imidlertid vært »tro« mot mitt opprinnelige ungdomsarbeid. De institusjoner og det miljø som jeg studerte for 16 år siden har nok endret seg betraktelig - men det er likevel å håpe at det iallfall er av generell interesse å børste støv av dette arbeid. 
seg, og han syntes arbeidet ble lettere năr han oppnådde en viss personlig kontakt. I sin omtale av herbergistene var han mere forstående. ${ }^{2)}$

\section{Hypotesen}

Siktemålet med undersøkelsen var å se om det var noen sammenheng mellom institusjonsstørrelse og kontrollørroller. Jeg antok, i for seg ikke særlig originalt - at den restriktive kontrollørrollen var mere typisk for store enn små institusjoner. Det ble bekreftet, selv om institusjonsstørrelsen ikke var eneste årsak til forskjellene. Dernest ville jeg undersøke om det var forskjeller i måten ansatte beskrev og opplevde klientellet på i store og små institusjoner. Denne hypotesen ble også bekreftet, i store trekk.

De ulike måter å forholde seg til, og oppleve klientellet på, gjenspeilte det seg i generelle sosialpolitiske og »hverdagsfilosofiske» holdninger? En forklaring kunne i så fall være at generelle holdninger fungerte som legitimering av ulike kontrollørroller - spesielt for den restriktive rollen var det en nærliggende problemstilling. Eller man kunne snu på flisa og spørre om de ulike kontrollørrollene reflekterte generelle holdninger, selv om jeg ikke regnet det som så sannsynlig. Ingen av disse hypotesene sto for nærmere etterprøving.

Planen for artikkelen er å drøfte forutsetningene for de ulike kontroll- og handlingsmønsterne med utgangspunkt i forskjellene mellom institusjonene.

\section{Metode og utvalg}

Statistikk og sitat er hentet fra intervjuer med 29 kontrollører, som arbeidet på 6 forskjellige herberger. 15 var ansatt ved det store herberget, som kunne huse ca. 500 herbergister på det meste. 8 kontrollører var tilknyttet 4 mindre herberger. ${ }^{3)}$ Disse herbergene - her kalt »småherbergene« hadde fra 17 til 37 sengeplasser. Klientellet på småherbergene var langt mere stabilt enn på det store herberget. Det store herberget lå sentralt i byens »lassaronstrøk« sammen med en rekke andre herberger - mens småherbergene lå spredt rundt $\mathrm{i}$ andre bydeler. 6 av kontrollørene arbeidet på et herberge som befant seg $\mathrm{i}$ en slags mellomstilling. Antal sengeplasser var omtrent som ved det største »småherberget«. Klientellet var derimot mere ustabilt. Og herberget lå i samme strøk som

2) Kontrollørene hadde ingen spesiell utdanning for yrket, og det ble heller ikke krevet annen relevant utdanning. De aller fleste hadde vært $\mathrm{i}$ andre yrker $\mathrm{i}$ lengre tid før de begynte som kontrollører. Kun 2 av dem hadde vært kontrollører fra de begynte sin yrkeskarriere. Kontrollørene på småherbergene hadde erfaringer fra de øvrige herbergene også.

3) Selv om samtlige ansatte ble intervjuet - så kan det reises innvendinger mot å bygge på prosentuelle forskjeller mellom de ulike herbergetypene siden totalantallet er relativt lite. En slik innvending er særlig berettiget hvis man ser på de enkelte spørsmål isolert. Når jeg likevel også gir en statistisk presentasjon, så er det fordi materialet inneholder klare tendenser sett under ett. 
det store herberget, og hadde en stor pågang på dørene. Kontrollørene måtte derfor forholde seg til langt flere herbergister og hjemløse over tid enn kollegene på småherbergene. Dette herberget går under betegnelsen »det mellomstore herberget."

Samtlige ansatte ble intervjuet. Intervjuene var delvis strukturerte; alle ble spurt om det samme, men det var ikke knyttet faste svarsalternativ til spørsmålene.

\section{DA DET GIKK SOM HARDEST FOR SEG \\ Fysisk maktbruk}

Herbergene var for de husville, hvorav mange hadde alkoholrelaterte problem. For de som både var arbeidsløse og hjemløse var drikkingen dagens samlende rituale. Kontrollørene skulle helst sile ut de som hadde drukket, ved å »lufte« dem eller avvise dem for natten. Det skjedde ikke konsekvent. Kontrollørene forsøkte å se herbergisten an, og i kalde vinterkvelder skulle det mye til for å avvise en kar. Men regelen var der, og det var grenser for i hvor stor grad kontrolløren kunne ignorere at herbergistene hadde drukket - blant annet - av hensyn til andre herbergister som klagde over at de fikk nattesøvnen ødelagt.

Kontrolløren forsøkte å hindre innsmugling av drikkevarer ved jevnlige kontroller.

»Vesker og plastikkposer blir undersøkt og herbergisten blir ransaket på kroppen om han har noen flasker. Denne sermonien kan herbergisten oppleve flere ganger på dagen. Det kan ende med den voldsomste krangel.« Avvisning og utvisning på grunn av fyll kunne føre til krangel og fysisk konfrontasjon mellom kontrollør og herbergist. »Disse problem er store for oss både i fysisk og psykisk forstand. Det er med på å gjøre dette arbeidet lite attraktivt.«

Det typiske på samtlige herberger var imidlertid at avvisningen foregikk $\mathrm{i}$ rolige former, men det var langt vanligere på det store herbergetat slike situasjoner utviklet seg i negativ retning. $87 \%$ (13) av kontrollørene på dette herberget fortalte at det ikke var uvanlig at de måtte benytte fysisk makt for å få ut herbergister som var full og krakilske. De vegret seg for å tallfeste hvor ofte det forekom. Halvparten karakteriserte det dog som relativt ofte, iallfall en gang pr. uke. Det vanligste var at et par kontrollører tok herbergisten i hver sin arm og geleidet ham ut, i langt sjeldnere tilfelle ble det slagsmål av det.

»Til tider er det nødvendig, men man skal være forsiktig med å gå for langt. Først prøver jeg å prate med dem, og hvis ikke det hjelper så har jeg jo ikke annet valg enn å kaste dem ut med makt. Det er 6 dager siden det sist skjedde.«

»Ja, svært ofte. Sist $\mathrm{i}$ forrige uke. Det er gjerne når folk skal ut at det er nødvendig. Først ber jeg dem om å være rolige, hvis ikke det hjelper bruker jeg makt for å få dem fjernet.« 
»De rolige folkene snakker jeg med dersom jeg skal ha dem ut. Dersom det er muligheter for bråk tar jeg dem imidlertid hardt med en gang.«

Av kontrollørene på det store herberget mente $67 \%(10)$ at de hadde for få ressurser til å kunne handskes med herbergistene $\mathrm{i}$ det mest tilspissede situasjonene, selv om de likevel ikke ønsket noen fysisk opprustning:

»Nei, men jeg er heller ikke interesseret i flere midler. Vi har kølle på jobben, men bruker den aldri. Det er også snakk om at vi skal få gasspistol, men det er jeg ikke tilhenger av. Jeg vil i det hele tatt ikke ha flere fysiske maktmidler.»

»Vi kan jo tilkalle politiet hvis det skulle være nødvendig. Når det gjelder midler ellers har vi faktisk en batong liggende her, men den benytter vi aldri. Det er jo noe man kan true med, men det er jo også farlig for vi kan provosere frem en situasjon hvor en faktisk blir nødt til å bruke den. Jeg hører de forteller at de brukte den mye før i tida her.«

Andre av disse kontrollørene påpekte at problemet vel så mye lå i mangelen på forebyggende midler:

»Jeg har ingen vanskeligheter med å handskes med folk, og jeg klarer også å kaste ut folk hvis det er nødvendig. Jeg tror også vi har nok midler på den måten, men vi har for lite midler av forebyggende karakter. Nå i sommerhalvåret kan vi riktignok avvise folk for eksempel når de er fulle, men det er det altfor drøyt å gjøre om vinteren, når kulda er på det verste. En kan risikere å ta livet av en mann på den måten. Det viser seg også at bortvisning ofte ikke hjelper. De kommer bare tilbake en halvtime seinere, og da vi har det samme bråket igjen.«

Det var forskjeller kontrollørene imellom på det store herberget, selvsagt. Noen hadde »kort lunte«, ble stresset, og kom opp i klammeri med herbergistene. Andre lærte av erfaring og ble gode menneskekjennere, som la raskere merke til hvilken tilstand herbergisten befant seg i. De klarte seg bedre i arbeidet. Men sammenlignet med de øvrige herbergene var miljøet tøffere på det store herberget. Kontrollørene hadde å gjøre med langt flere herbergister - flere hundre på det meste. Det var større gjennomtrekk i miljøet - og det oppsto oftere situasjoner som var vanskelige og uforutsigbare.

Kontrollørene på det mellomstore herberget var i en mellomstilling. Det var færre av dem $(50 \%)$ som benyttet seg av fysiske maktmidler enn på det store herberget $(87 \%)$, men de næret den samme avmektighetsfølelsen overfor de ekstreme situasjonene. På småherbergene var bildet et annet. Samtlige fortalte at det var unødvendig å bruke fysisk makt. De hadde bedre metoder dersom det oppsto en kinkig situasjon, som for eksempel overtalelse og formaninger. Og i motsetning til kollegene på det store herberget hadde de tid til å løse konflikter på den måten. 
"Siden det er så få her, lærer man den enkelte å kjenne«. Disse herbergene var også beskyttet ved at de lå såpass skjermet til, utenfor de hjemløses »allfarvei«. Kontrollørene risikerte ikke uventet besøk av fulle og »brysomme « fremmede som hisset seg opp fordi de ble nektet adgang. Småherbergenes egne herbergister tok seg riktignok en dram eller to, men ingen så det som noe stort problem.

\section{Vold i miljøet}

»Det er et nervepress å ha sånn jobb, jeg merket det godt selv«, fortalte en kontrollør. " Til tider er det mye tretting og slåssing, og når kolleger hisser seg opp, er det klart at det tar på, både for kontrollør og herbergist.« På det store herberget regnet $67 \%$ (10) av kontrollørene med at voldsstrusler fra herbergistenes side var en del av jobben, skjønt det var stor forskjell på hvor alvorlig slike trusler ble tatt. 7 av disse hadde blitt truet i løpet av siste uken.

»Ikke bare kontrollørene (som ble truet), men ofte også overfor kontrollørenes familie. I fjor var det til og med noen som trua med å drepe guttene mine. Det skjer med jevne mellomrom, altså at de truer.«

» jo det er vel heller regelen det når de blir nekta adgang.»

»Ja det forekommer. Men det er noe man sjelden eller aldri bør ta alvorlig. Og det forekommer bare når folk er under påvirkning av alkohol.«

$87 \%$ (13) av kontrollørene på det store herberget hadde erfaring med at kontrollører var blitt angrepet av herbergister. 10 av kontrollørene hadde vært vitne til eller involvert i slike episoder i løpet av siste år, og 5 i løpet av siste måned.

» ja. Her har det gått både i ribbein, lepper, tommeltotter og briller.«

»Kanskje 5-6 ganger i måneden. Med angrep mener jeg da alle former for angrep. Derfor er det viktig at vi selv opptret aggressivt og tøft av og til slik at vi kan bløffe dem.«

»Jeg for mitt vedkommende ble slått ned... fikk brudd på hjerneskallen. I slike situasjoner er det om å gjøre ikke å slippe dem for mye inn på seg. Det er ikke alltid bra å være for snill.»

»Jeg har ikke vært utsat for vold... men dette med vold er likevel et stort problem, for ofte er vi redde for at noe skal skje. Det hender at det blir brukt kniver her, men foreløpig har herbergistene kun brukt disse knivene mot hverandre."

»Kan du regne med å få hjelp av andre herbergister i slike situasjoner?« 80 \% (12) av kontrollørene på det store herberget svarte at de holdt det som utelukket eller svært lite sannsynlig. De svarene føyde seg inn i deres opplevelse av herbergistmiljøet.

»Det forekommer to, tre ganger i uken kanskje at folk slås. Det kan for så vidt være hvem som helst, men det er gjerne noen kroniske kranglefanter, håpløse 
typer som går igjen. Når noen prater i søvne eller bråker om natten, kan det lett bli slagsmål. Ellers er det svært vanlig at det blir slagsmål i forbindelse med fyll. For et par dager siden var det slagsmål sist. Jeg tror det er svært naturlig at det blir slagsmål mellom herbergistene når en tar den lille plassen de har med $\mathrm{i}$ betraktning. Det er altfor uforsvarlig å kjøre så mange inn på et sted som tilfellet er på dette herberget. $1 / 3$ av belegget hadde vært nok tatt plassen $\mathrm{i}$ betraktning. De som bor her får jo ikke noe privatliv. De har andre folk innpå seg hele døgnet, uansett hva de måtte synes om det å måtte bo på den måten. Det er klart at det skaper irritasjon og ergelser som igjen kan føre til slagsmål.«

»Brutaliteten blant klientellet har nærmest blitt en myte. Denne myten har for enkelte vakter ført til at de oppfører seg brutalt selv, muligens fordi de er usikre.«

Kontrollørene på det mellomstore herberget fortalte at trusler fra herbergistene var en sjelden affære. De hadde erfaring med at kontrollører ble angrepet av herbergister (67\% i motsetning til $78 \%$ på det store herberget) - men slikt forekom ikke så hyppig som på det store herberget.

»Husker ikke når, men en god stund siden. Det var en kar som dundra på døra klokka 1 om natta. Da jeg gikk ned for å stagge mannen så spyttet han meg $\mathrm{i}$ ansiktet gjennom gitteret $\mathrm{i}$ porten, jeg åpna porten og da jeg kom ut slo han meg i skulderen. Men trusler om politi endte det hele."

De regnet heller ikke med hjelp fra andre herbergister om de skulle bli angrepet, herbergistene fryktet represalier hvis de hjalp en kontrollør. Pågangen av herbergister og beliggenheten i byen gjorde miljøet mindre forutsigbart enn på småherbergene.

Spørsmålet om voldstrusler var knapt av interesse på småherbergene. Samtlige svarte også benektende på om kontrollørene ble antastet fysisk av herbergistene. Om kontrollørene ville bli hjulpet i en krisesituasjon var derfor et rent hypotetisk spørsmål.

»Jeg har aldri blitt angrepet av noen herbergister. Det er kanskje noen som har slengt ut en arm, men det kan jo ikke kalles aggresjon når folk er fulle.« »Jeg har bare opplevd det en gang i min tid som kontrollør og vedkommende var sinnsyk, så han kan ikke regnes med.«

Slagsmål mellom herbergistene var heller ikke noe problem på småherbergene.

\section{AVSTAND ELLER PERSONLIG KONTAKT "Ikke noe personlig for meg, nei!"}

På det store herberget svarte $60 \%$ (9) av kontrollørene at de foretrakk å holde herbergistene på avstand. For de 6 som ikke hadde noe imot personlig kontakt - 
gjaldt det $\mathrm{i}$ praksis kun et mindretall av herbergistene. „Det er jo så mange her.«

For de som holdt på avstanden til herbergistene, var den »omgangsformen" nærmest et prinsipp.

»Ikke noe personlig for meg, nei. Det lar seg simpelthen ikke gjøre, for da har man solgt seg. En risikerer da at herbergistene vil utnytte dette personlige forhold. En risikerer også mye mas og innpåslitenhet i utide.«

»Jeg vil ikke ha noen direkte personlig kontakt med dem. Arbeidet vil bli for vanskelig da. Jeg tror herbergisten lett vil bruke det mot en seinere, flere ville vel også forvente at de fikk spesialbehandling på grunn av det gode forholdet de hadde med kontrolløren.«

»Vi bryr oss ikke om enkeltpersoner, unntaken når de laker bråk. Det er mest vanlig å omtale en herbergist ved nummer istedetfor ved navn.«

„Vi kan ikke både vise en herbergist medlidenhet og sympati, og samtidig kaste ham brutalt ut.«

Ønsket om avstand ble begrunnet med at kontrolløren ikke ville binde seg. Og han ville være ubundet fordi han måtte ta upopulære avgjørelser, som for eksempel å vise ut en kar eller beslaglegge brennevin. De fleste kontrollørene på det store herberget beskrev arbeidet som lite variert, målsetningen var ren kontroll.

På det mellomstore herberget ga halvparten av kontrollørene uttrykk for det samme ønske som avstand til klientellet.

\section{"...det er faktisk helt påkrevet å snakke med dem."}

Det er vanlig med et mere personlig forhold til herbergistene fortalte $88 \%$ (7) av kontrollørene på småherbergene. $74 \%$ (6) av dem syntes også jobben ga muligheter for å hjelpe herbergistene på forskjellige måter. Personlig kontakt var nesten ikke til å unngå. Dessuten gjorde det arbeidet lettere, og i så henseende argumenterte de temmelig likt kontrollørene på det store herberget som holdt avstand til herbergistene.

»Jeg har mest personlig kontakt med herbergistene. Jeg handskes bedre med dem da. Jeg kjenner mere til hvordan de er, kjenner deres vanskelige og bra sider.« »Personlig kontakt. Siden det er så få her; lærer man hver enkelt å kjenne, ja, det er faktisk helt påkrevet å snakke med dem.«

En kontrollør som ble lært opp på det store herberget, og senere begynte på ett av småherbergene fortalte om hvor forskjellig opplæringen var på de to stedene. På det første stedet ble han rådet til å holde avstand, og dette rådet fikk han på det lille herberget: »Dersom jeg var nedlatende og trodde jeg var en småkonge måtte jeg regne med en vanskelig tid.« 
"Samhold giør sterk"

Kontrollørene på det store herberget var flere på arbeid samtidig, særlig på ettermiddagen da herbergistene ble sluppet inn. Det var også på ettermiddag- og kveldstid at det kunne bli bråk. Det var viktig å stå samlet overfor herbergistene, og så fikk man heller ta interne oppgjør på kammerset:

»Ute på gangen hvor vi alle er samlet så støtter vi den som har tatt en avgjørelse...« »Det er ofte uenighet om hvordan ting skal gjøres, men denne uenighet diskuterer vi bare når herbergistene ikke er til stede.« "Vi som er kontrollører har samarbeidet bra, og slipper ingen til slik at de kan gjøre oss ondt. Prøver en kar seg er vi tre stykker på ham med en gang.«

Samholdets verdi ble fremhevet $\mathrm{i}$ opplæringen av de nye, samtidig som opplæringen kunne være solidaritetsskapende i seg selv.

»Det er veldig vanskelig å gå gjennom denne opplæringsperioden uten å bli påvirket.« »Jeg merker på meg selv at jeg gjorde ting som jeg i grunnen ikke mente, men som jeg gjorde fordi jeg hadde sett de andre kontrollørene gjøre det samme.« »Etter tre uker var jeg som alle de andre.»

På småherbergene var kontrolløren alene på jobb, og kunne følge sitt eget løp. det hadde de i større grad tid til også. Forholdet til herbergisten var mere uformelt og til tider jovialt, ikke »dem og oss« som på det store herberget.

\section{KLIENTBESKRIVELSE OG $» H V E R D A G S F I L O S O F I \ll$}

Den skeptiske og den forstående beskrivelse

Flertallet av kontrollørene på det store herberget holdt avstand til herbergistene. Og 73 \% (11) svarte på direkte spørsmål at de fryktet herbergisten kom til å utnytte et personlig forhold.

»Når herbergisten skal oppnå ett eller annet skyr han som regel ingen midler.« »Hvis en kar har gitt en krone følger herbergisten opp senere og vil ha mere. Da har kontrolløren solgt seg sjøl.«

$86 \%$ (12) mente dessuten det var vanlig at herbergistene spilte syke: »Noen spiller syke for å ha en unnskyldning for at de ligger så dårlig an som de gjør.« »En del er flinke skuespillere. Jeg tror de spiller sjuke for å få penger og understøttelse. Stadig vekk treffer jeg på folk som sier: »Å, Jeg er så syk.« I neste øyeblikk springer de opp alle trappene i full fart.«

Også på det mellomstore herberget fryktet kontrollørene at herbergistene kunne utnytte et personlig forhold, men på småherbergene ble det holdt som usannsynlig. $88 \%$ (7) av disse kontrollørene så ingen fare $\mathrm{i}$ å ha personlig kontakt med herbergistene. På det mellomstore herberget og småherbergene svarte halvparten at det var utbredt at herbergister spilte syke. Fortsatt en forskjell fra det store herberget altså - men ikke så stor som på en rekke av de 
øvrige spørsmålene. De andre kontrollørene mente at herbergistene var syke nok som de var, de trengte ikke spille syke.

\section{Herbergistmiljoet}

På det store herberget var slagsmål og krangel et fast innslag. $60 \%$ (9) av kontrollørene klagde dessuten over at herbergistene anga og sladret på hverandre. »Ja, vi har noen faste sladrehanker som ikke er det grand bedre selv.« »Nei, det er lite samhold blant herbergistene. Det er mest baksnakkelse og tyverier fra hverandre. Splittelse og hat er iøynefallende trekk. Som eksempel på sladder kan jeg nevne at både vi og politiet bruker tystere for å finne ut forskjellige ting."

Tyveriene på herberget var et problem fortalte $86 \%$ (12) av kontrollørene. »De stjeler av instinkt tror jeg, og de stjeler uansett om de har behov for det..." »Har en mann hengt underbuksa si til tørk, så er den ikke der et kvarter seinere."

Ingen av kontrollørene på det store herberget beskrev herbergistene som renslige sånn i sin alminnelighet. »De eldre er vant med å bo i møkk og gjør svært lite for å forendre seg.« »Fylla sløver renslighetssansen. De har glimrende anledning til å bade her.«

Beskrivelsene av hvordan herbergistene holdt seg i klærne fulgte i store trekk det samme mønsteret. »De stamper gjerne klærne og går på fylla. Går i laser og filler.«

Kontrollørene på det mellomstore herberget delte seg i beskrivelsen av herbergistmiljøet, mens småherbergene ga en ganske entydig miljøbeskrivelse. $75 \%$ (6) svarte at de så lite eller ingenting til angiveri og sladder. »Nei, de er ganske tette der. Det forekommer ikke.« Samtlige skrøt av det gode samholdet mellom herbergistene. Og kun en av kontrollørene mente at tyverier var noe problem. Også hva kroppshygiene og klær angikk ga de herbergistene bedre attester enn hva herbergistene på det store og mellomstore herberget fikk av sine kontrollører.

\section{Kontrollorens opplevelse av herbergistenes opplevelse av kontrolloren}

Herbergistene hadde det materielt bedre på småherbergene, de var tryggere i de fleste henseende, og det fikk konsekvenser for hvordan de oppførte seg og stelte seg. Da kontrollørene beskrev miljøet på sine respektive herberger, beskrev de miljøer som var forskjellige. Men de tolket også sine inntrykk. Og i sine tolkninger var flertallet av kontrollørene på det store herberget mere skeptiske enn kontrollørene på småherbergene. Det ga de også en antydning om da det ble spurt om herbergistene følte seg sett ned av kontrollørene. $60 \%$ (9) på det store og $67 \%$ (4) på det mellomstore herberget svarte ubetinget ja. 
»Det er dessverre slik at nok en del av kontrollørene ser ned på herbergistene for så vidt... Ellers vil jeg si at det på en måte er et slags fiendtlig forhold mellom kontrollører og herbergister. Det er klart.«

»Svært ofte tror jeg. Det kan høres merkelig ut, men det har noe for seg med disse følelsene. Vi kontrollører er nemlig nødt til å holde herbergistene på avstand i tjenesten, og ofte må vi ta direkte avstand fra dem for å oppnå det. En konsekvens av det er jo at vi da kan virke overlegne og hovmodige, men vi har vel ikke noe særlig valg.«

Med unntak av en - svarte kontrollørene på småherbergene nei på det spørsmålet. »Her bruker vi en langt friere tone.»

\section{"Generelt sett."}

Flertallet på samtlige herberger klaget over at det ble giort for lite for herbergistene. Men det var likevel fatalisme å spore, og vel så mye på småherbergene. $60 \%$ (9) på det store herberget, $80 \%$ (4) på det mellomstore og $63 \%$ (5) på småherbergene var overbevist om at de som var løsgjengere kom til å forbli det til sine dagers ende. Men da uttalte de seg som løsgjengere i sin alminnelighet, ikke sine »egne« herbergister. »Ja, det er mange av dem som liker dette livet.« »Har de gått der en tid nytter det ikke å få dem vekk fra det.«

Det vil alltid være tapere - uansett samfunnsmæssige forhold, svarte det store flertallet på alle herberger. „Vi mennesker er ikke annerledes. « »Man vil alltid trekkes med undermålsindivider.« $73 \%$ (11) på det store herberget, $80 \%$ (4) på det mellomstore og $88 \%$ (7) på småherbergene ga slike svar.

Kontrollørene på småherbergene var dessuten mere tilbøyelige enn kollegene på det store herberget til å se på løsgjengernes situasjon som »selvforskyldt«. Halvparten av dem var også overbevist om at skjerpede forhold ville føre til færre løsgjengere. „Ja, det tror jeg. Vi så for eksempel under krigen at tyskerne sørget for at alle løsgjengere kom i arbeid.« »For eksempel torvkonene kan fortelle at under den tyske okkupasjonen var det ikke en løsgjenger i gata.«

Flertallet av kontrollørene på det store herberget $(67 \%)$ var uenige at det ville bli færre løsgjengere hvis disse ble underkastet for eksempel en hardere politsiær kontroll.

Selv om de generelle spørsmålene var tematisk beslektet med de konkrete spørsmålene - så var det ikke lenger noen forskjeller mellom herbergene av den typen som vi hadde regnet med å finne. Kontrollører på de småherbergene som foretrakk personlig kontakt med sine herbergister - var tilhengere av sterkere politsiær kontroll med løsgjengerne som gruppe. Og restriktive kontrollører på det store herberget hadde ingen problem med å svinge over i den liberale retning bare spørsmålene var generelle nok. 


\section{KONKLUSION}

\section{Store institusjoners rigiditet}

Store institusjoner forutsetter fastere rutiner og strammere styring, iallfallsett fra ledelsens synsvinkel. En slik byråkratisering møter flere krav, blant annet de som har med organisasjonens selvoppholdelse å gjøre. Men for klientene med sine individuelle behov, kan rutiner bli rigide, og sentrale avgjørelser er ikke alltid så forståelige.

Forbudet mot å komme beruset og å drikke på det store herberget var nødvendig for den daglige drift. Herbergister som møtte edru var lettere å ha med å gjøre, både for ansatte og for andre herbergister. Det hadde ikke nyttet å la »festen« gå på de store sovesalene utover nettene. Men samtidig var denne store soveblokken et tilbud til de hjemløse - hvorav temmelig mange hadde alkoholrelaterte problem. Kravet om å stille edru på den ene side, klienter med store alkoholproblem på den annen side - et slikt misforhold måte skape vanskeligheter. Avvisning, krangling, maktanvendelse og slagsmål ved inngangen kan føres tilbake til det misforholdet.

Gresham Sykes skriver i sin klassiker at fengselsledelsen var innforstått med at bare et mindretall av fangene var rømningsfarlige (Sykes, 1956). Betjentene kunne imidlertid ikke fastslå med sikkerhet hvem av fangene det var som utgjorde dette mindretallet, og derfor ble samtlige underkastet temmelige rigide sikkerhedsforanstaltninger. Situasjonen var en annen på herbergene - teknisk sett, potensielle »troublemakers« skulle holdes utenfor, ikke innenfor, men problemstillingen var den samme. Kontrollørene visste at bare et mindretall av herbergistene lagde skikkelig bråk i fylla, men til enhver tid å kunne sile ut disse var ikke mulig.

\section{Avstanden kontrollor og kontrollerte}

Kontrollørene på det store herberget hadde flere og mere ulystbetonte oppgaver, og de måtte forholde seg til et langt større antall herbergister. Flertallet foretrakk å holde herbergistene på avstand, et mindretall av kontrollørene kunne tenke seg et mer personlig forhold til dem, men i praksis var det bare mulig overfor noen få. Den uungåelige avstanden satte disse kontrollørene i en annen kontrollposisjon enn kollegene på småherbergene. På den ene side førte avstanden til at kontrolløren hadde færre måter å hanskes med herbergisten på i de vanskelige situasjonene. Det hjalp ikke så mye med en personlig appel overfor personer som man ikke engang husket navnet på. Avstanden gjorde det lettere å ta feil av herbergisten. Og på den annen side var det lettere å være hard, nettopp på grunn av avstanden. Det føyer seg til dette bildet at flertallet av kontrollørene opplevde herbergistene som »annerledes«, skitne, kranglevorne, bysomme og beregnende. 
Studier av totale institusjoner har gitt mange eksempler på avstand mellom personalgrupper og klienter, skjønt entydig er ikke bildet. Foruten størrelsen og stabiliteten i institusjonen, har bl.a. stigmatiseringen av klientene virket inn på hvordan personalgruppen har forholdt seg. Er klienten mentalt »syk«, og derfor behandlingstrengende, eller er han bare kriminell og »slem«? Heller »bad« enn »mad« har mange lovbrytere tenkt, vel vitende om at de "slemme» iallfall tillegges en viss tilregnelighet. Sykes tegner at annet bilde av forholdet mellom betjenter og fanger enn det ensidig antagonistiske, begge parter jenket seg til fordel for en mere avslappet atmosfære i institusjonen til daglig (Sykes 1956). På det store herberget var klientellet langt mere ustabilt enn i et fengsel, og det var mindre å kompromisse om - derav også mere av en antagonistisk avstand som har vært så typiske for totale institusjoner.

Den herskerteknik som betinges av og forutsetter avstand til de kontrollerte, går igjen på flere nivåer. Totale institusjoner er det første eksempel, la oss kalle det kontroll innen institusjonene. Nils Christie har studert dette tema siden begynnelsen av 1950-tallet. I en av sine bøker tar han det opp innen en bestemt institusjon, nemlig fangeleiren i krigstid (Christie, 1972).

Forholdet mellom mere »utadvendte« kontrollinstanser - som politiet - og større befolkningsgrupper, er et andet nivå hvor spørsmålet om avstand og nærhet har vært sentralt for både praktikere og forskere. I det norske mellomkrigssamfunnet ble denne herskerteknikken rendyrket da det ble opprettet et statspolitikorps i 1932, som var et halvmilitært urolighetspoliti. I motsetning til det øvrige politi var dette korpset direkte underlagt staten, og således ubundet av lokale bånd og lojaliteter (Johansen, 1977).

Norsk innvandringspolitikk og fremmedpoliti i mellomkrigstiden illustrerer et tredje nivå, nemlig forholdet mellom en nasjon og andre nasjoner eller etniske minoriteter. Det var vanskelig for utlendinger å slippe inn i Norge den gangen - og spesielt vanskelig for jøder, som ble sett på som langt mere »miesliebige« og fremmedartede enn svensker og dansker. Det falt lett for statsråder og fremmedpoliti å avvise og utvise utenlandske jøder, samtidig som mytene om jødene fikk leve fordi så få slapp inn i landet (Johansen, 1984).

\section{Kontroll og fysisk maktbruk}

Det var langt vanligere på det store herberget at kontrollørene løste konflikter ved å bruke fysisk makt, og de var mere utsatt for voldstrusler og for å bli angrepet. Fysiske konfrontasjoner mellom herbergistene var også mere utbredt, et fenomen som er studert i en rekke store institusjonstyper (Sylvester, 1977).

Håkon Lorenzen påpeker i en fersk artikkel at spørsmålet om maktbrukens legitimitet, varierer med synsvinklen, for eksempel politimannen eller arrestantens (Lorenzen, 1984). 
Legitimiteten kan i tillegg sees i et prosessperspektiv - hvor konfrontasjoner bygger seg opp fra diskusjon, krangel, legitim maktbruk og til rene voldshandlinger. Den grense som er viktig juridisk - blir sosiologisk mindre »interessant« fordi både legitim og illegitim maktbruk springer ut av den samme arbeidssituasjon og institusjonelle struktur. Når bruk av fysisk makt er en innarbeidet reaksjonsmåte - er grensen for det legitime lettere å overskride. »Kontrollørens» bruk av fysisk makt - er analysert på en rekke måter bl.a. som maktdemonstrasjon (Parson, 1964), »alternativ« straff (Skolnick, 1966), et middel til å presse frem tilståelser (Hopkins, 1931), en måte å avtvinge respekt på (Westly, 1970), en følge av rekruttering fra det militære (Fosdick, 1915) - og som et resultat av kynisme, frustrasjon og mistenksomhet innen den profesjon som har kontroll som yrke (Niederhoffer, 1966).

De ulike kontrollørgruppene skilte seg ikke ad i mere generelle holdninger, på den måten vi hadde ventet. Sånn generelt sett var ansatte på småherbergene vel så kyniske og restriktive - i den grad man kan utlede noe slikt i en intervjusituasjon. Fremfor å gjøre de harde teknikkene til et spørsmål om den enkeltes holdninger - til en slags maktens arroganse - synes svaret derfor snarere å ligge i de institusjonelle og materielle betingelser som kontrollørene arbeidet ut ifrå.

\section{Institusjon og omgivelsene}

Det store og mellomstore herberget lå i samme bydel sammen med en rekke andre herberger, varmestuer, sosialkontor og jernbanestasjon. De hjemløse var godt synlige i disse kvartalene med sine faste oppholdssteder på torg, gatehjørner og kaier. Den illegale brennevinsomsetningen foregikk også her - og den politsiære kontroll var strengere.

I motsetning til småherbergene som lå spredt $\mathrm{i}$ andre bydeler - hadde det store og mellomstore herberget et langt større »oppland« å betjene. Og med flere ukjente på dørene økte usikkerheten for kontrollørene. Herbergene var ikke totale institusjoner i teknisk forstand, men sosiologisk hadde de mye til felles med totale institusjoner. Herbergisten var »fanget« i rollen som herbergist, langt på vei var også hans selvbilde preget av det, særlig etter noen år i disse kvartaler og omgivelser (Johansen, 1973).

Om ikke herbergisten var teknisk »innesperret« - så var herbergisttilværelsen på det store og mellomstore herberget en del av den »innesperringen« eller renovasjonstradisjon som har vært et typisk måte å kontrollere Europas utstøtte på fra 1600-tallet av (Focault, 1973).

Den norske »løsgjengerloven«, som gjorde det mulig å sende en person på langvarig tvangsarbeid, hvis han gjentatte ganger var arrestert for fylle, bidro også til denne »renovasjon.« (Christie, 1960). 
Er »smått alltid godtu?

Kontrollørene på småherbergene var også »kontrollører«, men mere som den servicemindede politirollen som James Wilson (Wilson, 1968) beskriver - i motsetning til hans vaktrolle, som man kunne kjenne igjen på det store herberget. Disse kontrollørene fremhevdet fordelene ved å arbeide på små steder, og oppsto det problem definerte de dem på en annen måte. »Han var full, ikke agressiv. ${ }^{4}$

Kontrollørene på småherbergene var alene på jobb, det gjorde dem friere for kollegialt press. Og det var viktig å komme ut av det med herbergistene i det daglige, derfor kunne de være tjent med å overse en del »forseelser«, som når noen hadde drukket. Det var med disse kontrollørene, som lokalpolitiet i et gammelt amerikansk studie - at formelle reaksjoner og straff snarere kunne true enn styrke roen i lokalsamfunnet (Esselstyn, 1953).

Små institusjoner og små og tette samfunn er ikke alltid til de svakes fordel, og særlig ikke når fysisk nærhet og oversiktlighet kombineres med store maktforskjeller. I slike samfunn ble den sterke enda sterkere, han hadde både formelle og uformelle måter å kontrollere den svake på, og dessuten visste han så mye mere enn »kontrollører« i store og uoversiktlige samfunn.

Fagbevegelsen hadde sitt giennombrudd på de store arbeidsplassene hvor arbeidskollektivet sto sterkere og hvor arbeiderne ikke var bundet av nærheten til bedriftsherren - samtidig som de hadde styrken i at de var mange. (Bull, 1959).

»Nærheten« i terapeutisk samfunn på mentalsykehus og avrusningsklinikker er ikke ubetinget befriende for klientene. Men ledelse og personale er de sterkeste som i »gamle dager « når det kommer til et stykke - så har klienten følt seg ytterligere avmektiggjort av å måtte blottstille »sjel« og fortid. (Løchen, 1970).

»Kontrollører« i tette samfunn har betegnende nok opparbeidet seg avstand til de som skal kontrolleres, når nærheten har blitt generende. Mauren E. Cain drøfter det $i$ et studie av engelsk landsbygdpoliti (Cain, 1973). Norske erfaringer har også vist at politifolk har fungert dårlig i noen tilfelle når de har tatt tjeneste på hjemstedet - fordi de har tatt behov for å markere seg som politi overfor gamle naboer og jevnaldrende - og ikke bare være »Ola« eller »Jens«. Og da har de brukt hardere midler - enn hva nyinnflyttede politifolk har benyttet seg av.

4) Noen "siling« av kontrollørene fra de store til de småherbergene, ved at liberalerne søkte seg dit, gir ikke intervjumaterialet noe belegg for. Overflyttingen til småherbergene var mere situasjonsbestemt. Men en viss siling av herbergister må det ha vært til disse herbergene, yngre herbergister fikk ikke plass i det hele tatt. Dersom denne gruppen - som var temmelig liten på alle herberger - lagde bråk på det store herberget - så var veien kort til utvisning. Men da forble de i det ytre miljø, for så å gjøre nye forsøg på å slippe inn på herbergene. 
Kontrollens karakter og formål, og kontrollapparatets eller institusjonens størrelse er to sider av samme sak i studier som dette. Kontrollørene på småherbergene kunne føre et mildt regime overfor »sine« herbergister, kravene de stillte til klientellet var ikke så vanskelig å etterkomme. Derfor var det heller ikke nødvendig å holde avstand til herbergistene, »tettheten « $\mathrm{i}$ institusjonen tjente både »kontrollør« og »de kontrollerte.«

Adresse: Første amanuensis Per Ole Johansen

Universitetet i Oslo

Institutt for kriminologi og strafferett

Karl Johansgt 47

N-0162 Oslo 1

\section{LITTERATURLISTE}

Bull, Edvard:»Arbeidsmiljø under industrialismens gjennomburdd.« Oslo 1958.

Cain, Maureen E.: »Society and the policemans role« London 1973.

Christie, Nils: »Tvangsarbeid og alkoholbruk« Universitetsforlaget, Oslo 1960.

Christie, Nils: »Fangevoktere i konsentrasjonsleire.« Pax. Oslo 1972.

Esselstyn, T. L.: "The sosial role of the county sheriff.« Journal of criminal Law, Criminology and Police science. 44. July-August. 1953.

Focault, Michael: „Galskapens historie.« Oslo 1973.

Foscick, Raymond B: »European Police systems.« New York 1915.

Hopkins, Ernest J.: »Our Lawless Police.« New York 1931.

Johansen, Per Ole:»Hvite gutter og grønne forskere« Universitetsforlaget. Oslo 1973.

Johansen, Per Ole:»Menstadkonflikten 1931 «Tiden Norsk Forlag. Oslo 1977.

Johansen, Per Ole: »Oss selv nærmest. Norge og jødene 1914-1943« Gyldendal Norsk Forlag. Oslo 1984.

Lorenzen, Håkon: »Vold fra og mot politiet.« Nordisk Tidsskrift for Kriminalvidenskab. Nr. 2 maj 1984.

Löchen, Yngvar: „Idealer og realiteter i et psykiatrisk sykehus.« UNiversitetsforlaget. Oslo 1960.

Niederhoffer, Arthur: »Behind the shield. The police in Urban Society. New York 1966.

Parsons, Talcott: "Some reflections on the place of force in sosial Process. in Harry Ekstein (ed) »Internal War, Problems and approaches.« London 1964.

Skolnick, Jerome H.: "Justice without trial: Law enforcement in Democratic society.« New York 1966.

Sykes, Gresham: "Society of captives« 1956.

Sylvester, Sawyer F.: »Prison homicide.« New York 1977.

Westly, William A. »Violence and the police: A sociological study of Custom, and Morality.« Mass. London 1970.

Wilson, James Q.: »Varities of Police behavior.« Harvard University Press. 1968. 